\title{
Public Debt and Economic Growth in Egypt
}

\author{
Amal Soliman ElGhouty \\ Dept. of Economics, Modern Sciences \& Arts University \\ 26 July Mehwar Road intersection with Wahat Road, $6^{\text {th }}$ of October City, Egypt \\ Tel: 202-3837-1518Ｅ-mail: aasoliman1@msa.eun.eg
}

Received: July 30, 2018 Accepted: August 13, 2018 Published: September 5, 2018

doi:10.5296/ber.v8i3.13443 URL: https://doi.org/10.5296/ber.v8i3.13443

\begin{abstract}
The public debt has been representing a serious problem in Egypt during recent years. The main concern of the paper is to classify the extent of the debt problem in Egypt focusing on the post -revolutionary period since 2011. In the paper, reasons for the high level of public debt will be identified. Also, the economic growth performance will be analyzed simultaneously, then the relationship between both public debt and economic growth will be determined. Some guidelines for policymakers will be presented in the last section.
\end{abstract}

Keywords: Public debt, Economic growth, Budget deficit, Public debt as percentage of GDP

\section{Introduction}

The public debt has been representing a serious problem in Egypt during the recent years and the budget deficit as a percentage of Gross Domestic Product (GDP) as well follows as an important concern for the policymakers. Public debt is defined as the money owed by a country to other lenders other than itself, including individuals, businesses and other governments. It is the buildup of yearly budget deficits and the result of the continuous spending more than the intake of revenues by governments for many years (Amadeo, $\mathrm{K}$, 2018). As pointed out by Mohamed, H (2018) through the minister of Finance Amr El-Garhy, the plan is to reduce the debt from $107-108 \%$ in the fiscal year $2016 / 2017$ to $80 \%$ by 2020 . The decline has to be achieved through shrinking the deficit and reaching an additional of $2 \%$ of GDP with a rise in the average income per capita. The range aimed to be achieved is between $5 \%$ to $6 \%$ growth rate.

Mohamed, H (2018) added that the uptrend of the increase in public debt will continue in the future coupled with an increase in living standards. Yet, both the government and the Central Bank are still trying to decrease the public debt. On one hand, with the recent economic reform that Egypt Launched in 2016, the government introduced new taxes such as the Value-added tax (VAT), and reduced energy subsidies, all with the aim of lowering the budget 
deficit.

On the other hand, the government is trying to pursue ambitious programs with the aim of enhancing the small enterprises sector and increasing its participation by $10-15 \%$ and integrating them into the formal economy. Also, the growth of exports, especially the non-petroleum commodities is a major concern for the government. Last but not least, the focus on the Egyptian industries, especially the feeder industries ${ }^{1}$, and its contribution as a segment of GDP is another crucial step the government is aiming to achieve. At the same time, the public investment in 2019 is expected to increase especially that in Upper Egypt to EGP 149 billion and the government expenditures on basic commodities to target the low-income citizens are also expected to increase, with the expenses for social purposes only amounting to EGP 332 billion and the wages equal to EGP 266 billion (FocusEconomics).

Containing the public debt should be achieved by lowering the budget deficit and in this respect the International Monetary Fund (IMF) suggested accumulating more revenues to spend on the necessary social services and capitalize more in infrastructure, health and education services. The sources of revenues should come from reducing the tax evasions and reforming the tax system making it more efficient. In addition, removing the fuel subsidies which represent a high percentage of the government expenses is essential to keep the budget deficit at low levels especially with the changing international oil prices and the exchange rates (imf.org).

With this ambitious plan, the IMF anticipated that Egypt will be able to achieve a growth rate of $5.5 \%$ in 2019 , reaching a record of $6 \%$ in the year 2023. If public debt is properly utilized, it could lead to high economic growth and the increased capacity to repay external and domestic debt (Pakistan Economic Survey, 2012-2013).

Within the past ten years and with the persistent increase of the public debt in many countries, both emerging and developed as well, it is worthwhile to observe the relationship and the development of public debt and economic growth. Taking Egypt as an example, the main aim of this study is to trace the development of public debt and economic growth within the last eight years, in other words the post-revolutionary period.

\section{Historical Background}

As mentioned earlier, public debt is the sum of all financial obligations, domestic and external, owed by the government of a nation. During its history, Egypt had been suffering from rising levels of public debt that reached extraordinary records during the recent years due to the high levels of government spending and the decline in the sources of revenue of national income (alexbank.com).

Giving a brief account of the development of the government debt in modern Egypt, starting with Mohamed Ali, no debt was incurred at all because he strived to make Egypt independent and the international conditions helped him at that time (Amin, G., 2012). The foreigners were in no need to lend as at the time of Said and Ismail. Europe was busy during the wars of

\footnotetext{
${ }^{1}$ Those industries where its final products are used as raw materials for other industries like; iron and steel industry.
} 
Napoleon. Only Britain had finished its industrial revolution. It had lots of capital, and had good chance to invest it in Europe. The USA industrial revolution came later by about half a century with France and Germany. The weakness of the rulers after Mohamed Ali came coinciding with the need of Europe to lend.

Galal Amin (2012) added that it was Said pasha, since he ruled in 1854, who incurred lots of debts. He took loans from some European banks in Alexandria, and he also took the advice of Delespes $^{2}$ to issue treasury bills with duration 6 months to 3 years and with interest rates $15 \%$ and $18 \%$. The interest rate on loans at that time was 7\%. In 1860, Egypt got the first international loan from a French bank but with his name (1.2 million sterling pounds) with interest 6\%. In 1862, the first loan to the Egyptian government from a German bank (2.5 million sterling pounds) was paid with interest $11 \%$. When Said died, the total loan incurred by Egypt was 18 million pounds or 5 times the revenue of the Egyptian government a year before he died. Most of these loans were due to his own expenses. Also, the people surrounding Said pasha made him incur lots of loans that were not directed to good projects.

Said made the mistake of approving 2 conditions 1) providing labor in digging Suez Canal which led to the withdrawal of 60000 labor from agriculture. 2) giving the Suez Canal company the lands near the canal providing drinkable water. Ismail wanted to cancel these two conditions and this costed him 4 million pounds, to be paid in installments over 16 years plus the debts of said, if paid yearly could have cost the government no more than $9 \%$ of their revenues plus decreasing government expenditures by less than $20 \%$. Ismail as well as Sadat did not do that, so expenditures increased. In 1876, the Egyptian treasury became under lien (debt reached 91 million pounds), which if paid annually could represent $80 \%$ of the government revenue.

Galal Amin (2012) added that during the first 3 decades of the British Occupation (1882-1914), there was rapid economic growth to serve the creditors interests and to get sufficient income to serve the debts. 24 to $40 \%$ from the export revenue went to serve the debt. During the first 30 years of the occupation, Egypt paid 145 million pounds as debt servicing. During the first world war and after it, there was cumulative surplus in the balance of payments (BOP) worth 139 million pounds and most of it went to service the debt. From 1914 until 1934, debt decreased to 39 million pounds from 86 million pounds.

The second World War was a turning point. Egypt was able to pay all its debts and become a creditor nation, due to the expenses of the allied troops in Egypt. The expenses of Britain were 340 million pounds or 8 times the total of Egyptian debt at the beginning of the war. Egypt suffered a lot to get its money back. By 1956, there was no debts at all incurred by Egypt.

From 1959 until 1965, Egypt signed two loan agreements with the Soviet Union, one to finance the iron and steel complex in Helwan, and the other to finance the first stage of the High Dam and another agreement for economic cooperation with West Germany. There was an increase in the expenditures on social services and the army. The increase in imports was

\footnotetext{
${ }^{2}$ A French architect who initiated the project of Suez Canal and presented the idea to Said pasha, after being rejected initially by Abbas pasha.
} 
low but greater than the increase in exports plus the Suez Canal revenues. The debt during that period was EGP 800 million (5\% of GDP), from the USA (300) and from the Soviet Union (500). Industrial employment increased. The obligations of Egypt increased. These include the payment of 67.5 million sterling pounds as compensation for shareholders (Greek, Swiss, French, ...etc) in the nationalized Suez Canal company and for the Sudan in return for the inundation of land as a result of the High Dam. In 1965, there was bad external shock (assistance stopped from USA, 1967 war). This was mainly because of the USA disagreement with the Egyptian policy. West Europe also stopped aid. In 1967, we lost foreign exchange, Sinai Oil and tourism because of war and Suez Canal closed. Soviet Union aid increased but yet was not sufficient. The main source of external aid after 1967 was the Khartoum agreement of 1968 signed by Saudi Arabia, Kuwait and Libya and according to which Egypt obtained grants amounting to an average of \$286 million annually. In 1970, total external debt of all kinds was \$5billion.

Economic development had to pay the full price of 1967 war. So, from 1967-1975, rate of investment was low to save resources for the army. Deficit in balance of payments increased, we lost our resources of exports, Suez Canal closed and imports increased. This was beside debt service to meet from last periods.

Galal Amin divided the period into: 1967-1970, 1970-1975. So, we are comparing debt situation in 2 periods: Nasser and Sadat periods. From 1967-1970, there was more reliance on grants more than borrowing. In the 1960s, the annual growth rate of external debt was on average 9\%, short-term borrowing grew yearly on average of 25\%. From 1970-75, Public debt in 1975 (\$6.3bn). Average annual growth rate of external debt was 23\%, short-term borrowing grew yearly on average of $55 \%$. The reason mainly was because of rising imports. From 1970-75, exports grew $240 \%$ while imports grew $350 \%$.

The seeds of external debt were sown in 1975. In 1975, the debt situation seemed to have reached a point which Sadat expresses as a "zero situation". He said that nobody informed him of how serious the situation had become, and he thought the figures presented to him were in dollars and not in sterling pounds. Two years later third of the debt was due. Egypt had to pay $\$ 2$ billion in debt service. This is equal to $78 \%$ of all our export proceeds. In 1977-81, there was an Oil boom, Oil exports were multiplied ten times. Egypt export revenues increased by $\$ 7$ billion. This is equal to $86 \%$ of total debt. Labor remittances also increased. Egypt's terms of trade rose by $81 \%$. Foreign exchange revenues multiplied about 4 times. Actually, we did not pay the debt and debt increased by $76 \%$. In 1981, external debt is equal to $14.3 \%$ of GDP. This is equal to \$30billion.

From 1982 until 1987, we had a serious debt problem and a distorted economy. In 1981, Total Egyptian external indebtedness of all kinds was $\$ 30$ billion. In 1982, there was big economic conference by president Mubarak. The recommendations of this conference were to restrict imports of everything including capital and intermediate goods even if this came at the expense of investment and growth and to reduce military expenditures.

The problem was that the recommendations were not specific enough. They were not applied. Policies used after 1992 were the same as the 1970s. External borrowing increased by $25 \%$ to 
reach rate of growth $8.1 \%$. This was contradictory. Actually, the recommendations were never realized. There was mild restrictions on imports and heavy military expenditures. In 1986, rate of growth of GDP was $1 \%$. Total debt was $26 \%$ higher than in 1981 . But the rate of growth of debt was lower than in 1970s. In the 1970s, debt grew faster when there was no need to borrow. In the 1980s, debt grew slowly when there was need to borrow.

In 1990-1991, the Gulf Crisis crashed and there were unexpected events. Several countries started to commit financial and commodity assistance to Egypt because Egypt was hurt by the Gulf crisis (labor returned back, no labor remittances) and we sent our troops there. Our burden on the B.O.P was \$6billion. 6 months after, \$5bilion came from different countries such as Saudi Arabia and United Arab Emirates to relieve our problems. B.O.P was superior to previous years. Also, commodity assistance of $\$ 24$ billion as grants came from France (Wheat, Flour, Meat), Coal from Canada and Wheat from Australia. USA cancelled $90 \%$ of Egypt military debt to USA which was $7.1 \%$ of external debt. Arab countries cancelled $\$ 6.6$ billions of debt, reducing our interest obligations by $\$ 1$ billion/year. We started negotiations with Paris Club, and we reached agreement in May 1991 to cancel 50\% of Egypt's debt which is equal to $\$ 20$ billion. This has to be done on three steps: 1) Exemption of $15 \%$ effective now. 2) Another 15\% after 18 months (November 1992). 3) Last 20\% after another 18 months. The last two steps were conditional upon our economic performance in this period (Economic Reform). What happened is that they exempted 15\% but in 1993.

As said by Megahid, A. (2017), Egypt missed the opportunity to restart its economy in May 1991 after being in debt for decades, especially after the United States and 17 other creditor countries exempted Egypt from half of its debt following Cairo's participation in the Operation Desert Storm. Due to poor economic management, corruption and regional instability, Egypt accumulated additional debt rather than building on this debt relief.

The rate of growth of the public debt was more than the growth rate of the overall economy over the period from 1985-2006. Certainly, the economic reform and structural adjustment program (ERSAP) which was implemented from 1991 was one of the reasons behind the accumulation of public debt. After 2000, the high public sending in inefficient sectors, the increase in the costs of imported materials along with the high subsidies and the wages of employees led to rapid growth of the public debt (El-Mahdy \& Torayeh, 2009).

According to 2014 statistics, Egypt comes next after Lebanon among the Arab countries in the high ratio of public debt to GDP (87.1\%) and Lebanon (133.4\%). The domestic debt in Egypt had increased from LE 97 billion in 1991 to LE 246 billion in 2000 reaching LE 593.5 billion in 2006. By mid 2007, the overall unpaid domestic debt was more than LE 637 billion. $^{3}$

\section{Literature Review}

Two studies dealt with public debt sustainability in Egypt. One study is El-Mahdy and Torayeh (2009) who examined two issues related to debt in Egypt. The first is the effect of domestic debt on economic growth during the period from 1981 to 2006 . They found out that

\footnotetext{
${ }^{3}$ CBE: Economic Review, various issues.
} 
domestic debt had a negative impact on economic growth. The second issue is the sustainability of domestic debt. They found out that domestic debt in Egypt during this period has been sustainable. The second study was conducted by Abu Taleb and Hamad (2010). They examined the foreign debt policy in Egypt during the period from 1985 to 2008 and compared it to the optimal policy ${ }^{4}$, and found out that Egypt's foreign debt was greater than the optimal level before 1997. However, after 1997, the foreign debt was below its optimal level. A recent study by Massoud, A. (2015) talked about the size of the public debt problem in Egypt, and he found out that Egypt's public debt is supposed to be sustainable until the year 2020. He also added that with the increase in economic growth, the impact of reducing public debt in Egypt will be significant but with more rational application of the fiscal policy.

Krueger (1987) found that after oil crisis, large deficits in the current accounts are encountered by the oil importing countries whereas oil exporters were able to generate current account surpluses. The surpluses are lent to commercial banks, which in turn finance the deficits of oil importing countries. Sachs (1990) showed that in case higher taxes are imposed to cover the debt servicing, then these taxes could possibly reduce the economic growth. Levy and Chowdhury (1993) also found that the increase in public external debt dampens economic growth by depressing capital formation and encouraging more capital flight.

Smyth and Hsing (1995) found that up to approximately $38.4 \%$ of GDP, external debt enhances economic growth. Afterwards, it is reducing economic growth. In addition, Pattillo et al. (2004) concluded that the spread of the negative effects of external debt on growth are very clear from total factor productivity (TFP) and investment (physical capital accumulation). He also discovered that in countries with high debt levels, doubling of debt would reduce the GDP growth by approximately $1 \%$.

According to Cunningham (1993), economic growth is negatively affected by the debt burden through its adverse effects on the efficiency of capital and labor. Fosu (1996) also concluded that debt burden results in limiting the GDP growth and further estimated that on average a country having rising levels of debt, faces $1 \%$ reduction in GDP growth rate. Moreover, Iqbal and Zahid (1998) and Chowdhury (2001) came to similar conclusion that debt is harmful for economic growth. However, Lin and Sosin (2001) empirically found that debt has negative and significant effect on economic growth in African countries but insignificant effect for Latin American countries. But for Asian countries, the relationship was positive but insignificant. From these findings, it is clear that efficient utilization of debt is very important for its impact on economic growth.

Another important aspect of the indebtedness is the problem of debt overhang. In the literature two debt overhang concepts have been discussed. Sachs and Williamson (1986) explained the first concept - when indebted countries pay their debts or service them then real resources are relocated from the private sector to the public sector. Feldstein (1986) elaborated the second concept - namely, that government needs to levy taxes on private

\footnotetext{
4 The optimal policy as described by Escolano \& Gaspar (2016) is one which determines the tax rate annually to cover the expected government spending in addition to the debt servicing from previous periods each year.
} 
sector to finance debt obligations, which results in worsening the returns from investment, and leading towards decrease in investment and economic growth.

Sawada (1994) had the same opinion that in heavily indebted countries current external debt is more than their expected present value of future returns; therefore, countries face the debt overhang problem. However, Afxentiou and Serletis (1996) were unable to find out the underlying relationship between external debt and GDP and got to the conclusion that debt overhang is rather overstated. Deshpande (1990), Mahdavi (2004) and Fosu (2007) argued that expenditure on debt servicing may relocate the public expenditures away from social sectors like health and education, and public investment, which hinders the economic growth. Clements et al. (2003) also supported the debt overhang hypothesis. Elmeskov and Sutherland (2012) supported the view that public debt overhangs impacts growth through increased cost of capital. Sen et al. (2007) also came to the conclusion that due to severe debt overhangs effect; economic growth in Latin American economies slowed down. However, debt overhang does not exist in Asian countries.

There is another important concept related to the external indebtedness issue - namely the "crowding out effect". According to Warner (1992) and Taghavi (2000), external debt tends to crowd out investment. Similarly, Serieux and Samy (2001) found that the strong effect of crowding out effect of external debt could be felt more on the quality rather than the rate of investment. Cohen (1993) reveled that in highly indebted developing countries, the level of external debt has no remarkable effect on reducing the rate of investment. Ramakrishna reveals that Ethiopia is encountering debt overhang situation along with severe debt servicing problem.

Were (2001) found that external debt has a negative impact on economic growth and private investment in Kenya. Yet, current debt flows fuel investment while past debt accumulation discouraged investment. Karagol (2002) found that external debt had a negative impact on GNP both in the short-run as well as in the long run. He also claimed that the causal relationship between debt servicing and GNP is due to the fact that borrowed resources were misused in the past. Habimana (2005) found that different debt variables had significant and negative impact on investment in Rwanda. On one hand cost of debt servicing is affecting harmfully public investment. On the other hand, higher taxes have a negative effect on investment returns, but they are necessary to service debt obligations.

Abbas (2005) declared that the decision to shift from external to domestic debt is full of difficulties. He also found that the relationship between domestic debt and economic growth is negative. Latter on Abbas (2007) realized that if domestic debt exceeds the $35 \%$ of the bank deposits then it depresses economic growth. However, Blavy (2006) came to the conclusion that maximum level of public debt should be $21 \%$ of GDP and doubling of public debt would decrease productivity growth by about $1.5 \%$.

The policymakers are very much concerned about the issue of public debt in developed countries especially after the recent financial crisis. By utilizing the data of 18 Organization of Economic Cooperation and Development (OECD) countries during the period 1980-2010, Cecchetti et al. (2011) found that once public debts exceed the maximum level of $85 \%$ of 
GDP, economic growth starts to decrease. Kumar and Woo (2010) also found inverse relationship between debt and growth. An increase of 10 percentage points in debt/GDP ratio results in a reduction in economic growth to around 0.2 percentage points annually. However, Panizza and Prebistero (2012) concluded that the evidence is very weak in developed countries that public debt would reduce future growth. While in the case of developing countries where a significant portion of the debt is external, the debt overhang argument has more power.

Additionally, Reinhart and Rogoff (2010) found that debt to GDP ratio of $90 \%$ and above is coupled with lower economic growth in both advanced and emerging market economies. However, low levels of external debt to GDP ratio around $60 \%$ are associated with unfavorable outcomes for economic growth of only developing market economies.

Stabilizing the debt to GDP ratio at a target level (65\%) as in the case of Egypt makes the issue of sustainability much more difficult. To be more realistic, insuring sustainable path for debt means that the government should continue to operate under its current fiscal policy without creating a rapidly growing debt to GDP ratio. Certain measures and policy implication had to be adopted to bring down the ratio of public domestic debt to the sustainable level -even in higher level- without sacrificing high growth (El-Mahdy and Torayeh, 2009).

From the review of the preceding studies in literature, it can be concluded that most of the studies are on the correlation between external debt and economic growth, ignoring domestic debt completely or referring to it on narrow basis. There are differences in the socio-economic conditions of different countries, which makes it essential to conduct a country specific study. The current study is a trial to highlight the recent trend in the public debt and its relationship to economic growth.

\section{Reasons for the Increase in Public Debt Post Revolution}

Identifying the factors that cause the high level in the debt/GDP ratio is not always recognizable as said by Abas, et al. (2013). In some instances, it was found that the former ratio was high due to low or negative growth rates, but the fundamental correlations differ across countries and time. Other factors could be inflation, interest rates and stock-flow adjustments. ${ }^{5}$ Other factors could also be but not limited to; the functioning of the national economy especially the way it recovers after shocks and the eagerness of the policymakers and their willingness to implement sounf fiscal reforms. Abiad and ostry (2005) stressed on the nations' ability to generate surpluses and their historical experience in managing the debt issue and its budget. Public debt invested in growth enhancing areas such as infrastructure is good in generating surplus unlike the debt that finances the ongoing government expenditures which is considered a constraint on the fiscal budget over the medium and long term.

The Egyptian domestic debt consists mainly of Egyptian public loans generated through

\footnotetext{
5 "The stock-flow adjustment (SFA) is the change in the value of government debt minus the flow of yearly deficit/surplus. It is commonly known that deficits lead to the increase in debt levels, while surpluses depresses them." (Eurostat)
} 
banks, individuals and non-banking institutions. To be more specific, domestic debt is mainly financed through the issuance of treasury bills (t-Bills), about $81 \%$ of it, in addition to treasury bonds (T-Bonds). According to 2015 statistics, $79 \%$ of these Treasury Bills were held by Egyptian banks, the largest creditor to the government. Egypt's three state-owned banks hold about $50 \%$ of these bills, while the remaining percentage is held both by private banks and foreign banks-branches.

The increase of the debt that Egypt witnessed in the five years from 2010 until 2015 was tremendous reaching nearly EGP 2.1 trillion in 2015 relative to EGP 888.7 billion in June 2010.

As mentioned by Megahid, A.(2017), following the popular uprising in January 2011and the downfall of President Hosni Mubarak system, the foreign debts amounted to $\$ 36.5$ billion. By 2014 , the debt reached $\$ 46.1$ billion and increased thereafter due to the major economic, political and security measures.

The main reason behind the rising debt is mainly the increase in government expenditures at an accelerating rate more than the revenues, leading to an increase in the budget deficit. On the payments side, certain expenses such as; salaries, subsidies, interest payments and public investments have significantly hiked after 2011 Revolution, while the revenues, especially tax earnings, were adversely affected by the political and economic instability after the revolution. The repayment of domestic debt service alone(including the interest and principal payments) represented $37.4 \%$ of government expenditures in 2013/2014, compared to $23.9 \%$ in 2009/2010(alexbank.com).

Interest rates on T-Bills increased steadily after 2011 due to political and economic instability. They started to decrease during 2013/14 after the inflow of Gulf aid to Egypt and the upgrading of Egypt's credit rating. However, interest rates increased again in 2014/15, due to the increased government's need for debt and the devaluation of the Egyptian Pound.

The tourism sector in Egypt, which represents nearly 4\% of GDP, was negatively affected after 2011 due to post revolution instability and again after October 31, 2015, due to the bombing of a Russian passenger plane over Sinai. The accident was the reason behind the suspension of many flights from different countries to Egypt, reducing a main source of foreign currency revenue.

Also, as said by Megahid, A. (2017), if borrowing by the government continued with the current levels, there will be a risk of default on interest payments. Approaching the end of the fiscal year 2016-2017, the Central Bank announced that foreign debts alone reached \$79, with an increase of $42 \%$ compared to the previous year. While the bank claimed that the amount of the debt was within the appropriate limit since it did not exceed $45 \%$ of the Egyptian GDP, yet the economists showed some concern especially that the combined external and domestic debt represented $130 \%$ of GDP.

\section{Performance of Economic Growth in Egypt Post Revolution}

Analyzing the five years after the revolution, there was rapid political change, social 
disturbance and economic instability. The statistics of the Central bank of Egypt shows that at the disrupt of the revolution, the Egyptian economy was very stable and healthy. By the mid 2000s, GDP, on average, was $7 \%$ annually. The accumulated foreign reserves by 2010 , just before the revolution, was $\$ 35$ billion, covering 8.6 months' worth of imports. In the same year, according to World Bank indicators, GDP per capita was $\$ 2,600$, increase of almost $50 \%$ since 2006. This does not mean that the growth was equally shared. Most of this growth was due to consumption, while investment was concentrated mostly in capital-intensive industries such as: petrochemicals and energy, that do not involve job creating opportunities.

Corruption and red tape were other important characteristics of the economy, resulting in a large informal sector. A study conducted by the Egyptian Centre for Economic Studies in 2014 showed that the informal sector is representing two-thirds of the value of the formal economy. World Bank figures showed also that in 2010 the rates of poverty were 25 percent, up from 16.7 percent in 1999.

In the aftershock of the revolution, ambiguity over the final outcome of the coming stage led to economic slowdown and low economic growth. Over a period of five years post revolution, Egypt passed through different systems, from the Supreme Council of the Armed Forces (SCAF) to president Mohamed Morsi, who was in turn removed by SCAF, and now ruled by President Abdel Fattah al-Sisi.

In November 2015, the CBE reported that the net reserves were $\$ 16.4 \mathrm{bn}$, or 3.4 months' worth of imports. The indicators improved steadily later on, showing some international confidence in the Egyptian economy. So, the World Bank indicators showed foreign direct investment (FDI) inflows amounting to $\$ 4$.8billion in 2014, slightly up from $\$ 4$.2billion in 2013, but far below the $\$ 11.6$ billion of 2007.

Egypt's GDP growth rate has fallen as well since 2011. According to Shanta Devarajan, chief economist for the Middle East and North Africa region at the World Bank: growth in Egypt has been on average of 2-3 percent a year, which is below the potential and its past growth rates, but good given the circumstances (middleeasteye.com).

The picture was not entirely gloomy. Brendan Meighan, an economic researcher at the American Chamber of Commerce in Egypt stated that the performance of the energy and real estate sectors was remarkable over the five years post revolution. In August 2015, Italy's ENI oil and gas company announced the discovery of a gas field in Egyptian waters, the Zohr field, which was estimated to contain up to 30 trillion cubic feet of gas, sufficient to satisfy the country's energy needs for decades.

Huge investment plans began to attract new attention after being ignored. The Toshka project, as an example has been renewed. This project alone is supposed to reclaim 1.5 million feddans of land from the desert at a cost of about $\$ 766$ million.By June 2015, about 500,000 feddans had been reclaimed since work started in 2014.

In addition, the government had ambitious plans for an industrial and logistics zone along the Suez Canal known as the Suez Canal Corridor Expansion. Building a second canal costed \$7.7billion, but funded mainly from bonds. The prospects for this project is to double canal 
traffic by 2023, stimulate more revenues, develop industrial production and leads to an estimate of one million new jobs created.

Lately, as mentioned by Megahid, A. (2017), Egypt has pointed to a return back of tourism in 2017 , with revenues ( $\$ 3.5$ billion), representing $170 \%$ compared to the previous year. The number of tourists rose 54\%, reaching 4.3 million in 2017, after European countries lifted the flight suspensions to Sharm El-Sheikh.

\section{Relationship between Public Debt and Economic Growth in Egypt}

High debt ratios do not essentially lead to macroeconomic crises. It depends mainly on the term structure of the debt and interest rates and whether the government policy is realized by market members to be consistent with falling debt ratios in the longer run (Alba, P. et al., 2004). But, it is also known that with unlimited increase in debt, the economic growth will be negatively affected in the long run. Private investment is crowded out by high level of debt, imposing a constraint on fiscal policy. If the government is able to service its debt without imposing costly economic and political measures, the debt in this case is considered sustainable (Massoud, 2015).

Reinhart and Rogoff (2010 and 2012) claim that a debt/GDP ratio exceeding 90\% affects economic growth negatively. Pescatori et al. (2014) found that higher debt is accompanied by a high degree of output volatility. Abiad and Ostry (2005) added that the build-up of public debt is very destructive to growth over the long run due to what is known as a debt overhang, and the countries that cannot manage the increasing debt over the long term will experience debt unsustainability problems.

As confirmed also by the former Egyptian Prime Minister Ali Lotfy, the debts in Egypt reached a point that should be "a wake-up call" for decision makers, as the current level of debts will make it harder for the government to make further investment or reduce the budget deficit (Megahid, 2017).

One third of the government spending goes to debt servicing, and of course this will come at the expense of development and welfare programs and more subsidies cuts. Additionally, one third of the government budget goes to the salaries of almost six million civil servants. In this case, Egypt is facing a big obstacle to its development plans.

Megahid, A (2017) added that receiving the full amount of a \$12 billion loan from the IMF is conditional on following a strict economic reform program. Of course, the loan helped Egypt in its development plans and reducing the budget deficit, but still it adds the IMF to the list of creditors that Egypt owes to. The worst scenario that could follow for us to reach a point at which borrowing is needed to repay loans. In this case, these loans come at the expense of the living standards of the people because, instead of spending money on development, the government will have to spend money to repay the loans.

Although many investment projects were launched by the government during the past three years leading to higher growth rates encountered more than before, yet the public debt is still not under control. The budget deficit is shrinking somehow as a percentage of GDP and the 


\section{Macrothink}

Business and Economic Research

ISSN 2162-4860

2018, Vol. 8, No. 3

objective of the government is to reduce it even more, but serious efforts have to be made to achieve this target. It is a hard equation to be maintained and it might come at the expense of economic growth.

One positive aspect could be the tourism sector, which began to flourish since the past year. This could be a good evidence that the economic reforms are paying off. The foreign currency needed by the economy to grow will increase and this will attract more investments. In this case, the fear from the debt will no longer be there since the economy is moving forward.

The only way to contain the public debt is lowering government spending and raising taxes, and this what the Egyptian government was trying to do the past three to four years. Yet, due to factors outside the government's control such as the devaluation of the Egyptian pound and the rise in the overall international price levels, the public debt is still increasing and is expected to increase even more.

\section{Statistical Analysis}

Some macroeconomic indicators with other statistical figures will give an illustration of the whole picture post revolutionary period.

Table 1. The GDP with other related government debt indicators in Egypt

\begin{tabular}{|l|l|l|l|l|l|l|}
\hline Indicators/Years & 2012 & 2013 & 2014 & 2015 & 2016 & 2017 \\
\hline GDP per capita(USD) & $2,593.2$ & $2,591.1$ & $2,608.4$ & $2,665.4$ & $2,725.7$ & 2785.37 \\
\hline GDP (USD bn) & 279.4 & 288.6 & 305.5 & 332.7 & 332.9 & 235.37 \\
\hline $\begin{array}{l}\text { Economic Growth (Real GDP, } \\
\text { annual variation in \%) }\end{array}$ & 2.2 & 2.1 & 2.2 & 4.2 & 3.8 & 4 \\
\hline Fiscal Balance (\% of GDP) & -10.8 & -13.7 & -12.1 & -11.5 & -12.2 & -9.5 \\
\hline Public Debt (\% of GDP) & 80.3 & 87.1 & 90.5 & 85 & 92.3 & 101.2 \\
\hline
\end{tabular}

The source of data: The Central Bank of Egypt, various issues of annual report

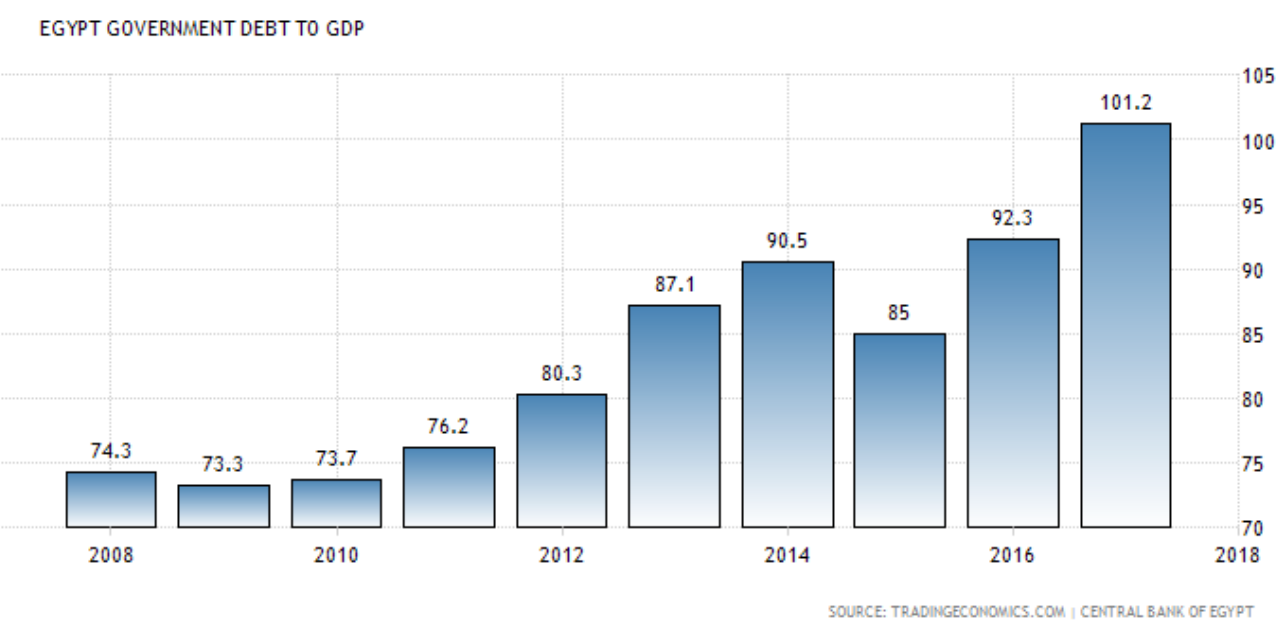

Figure 1. Development of the government debt to GDP ratio from 2008 until 2017 


\section{Macrothink}

The government debt reached 101.20\% of the country's Gross Domestic Product in 2017. The average was 87.91 percent from 2002 until 2017, reaching a peak of $102.30 \%$ in 2003 and a minimum of $73.30 \%$ in 2009 , as shown in figure 1 . According to the monthly bulletin of the Central bank of Egypt issued on May 2018, the domestic debt alone reached EGY 3414.4 billion, or $83.8 \%$ of GDP by the end of December 2017, an increase of about EGY207.8 billion during the period from July 2017.

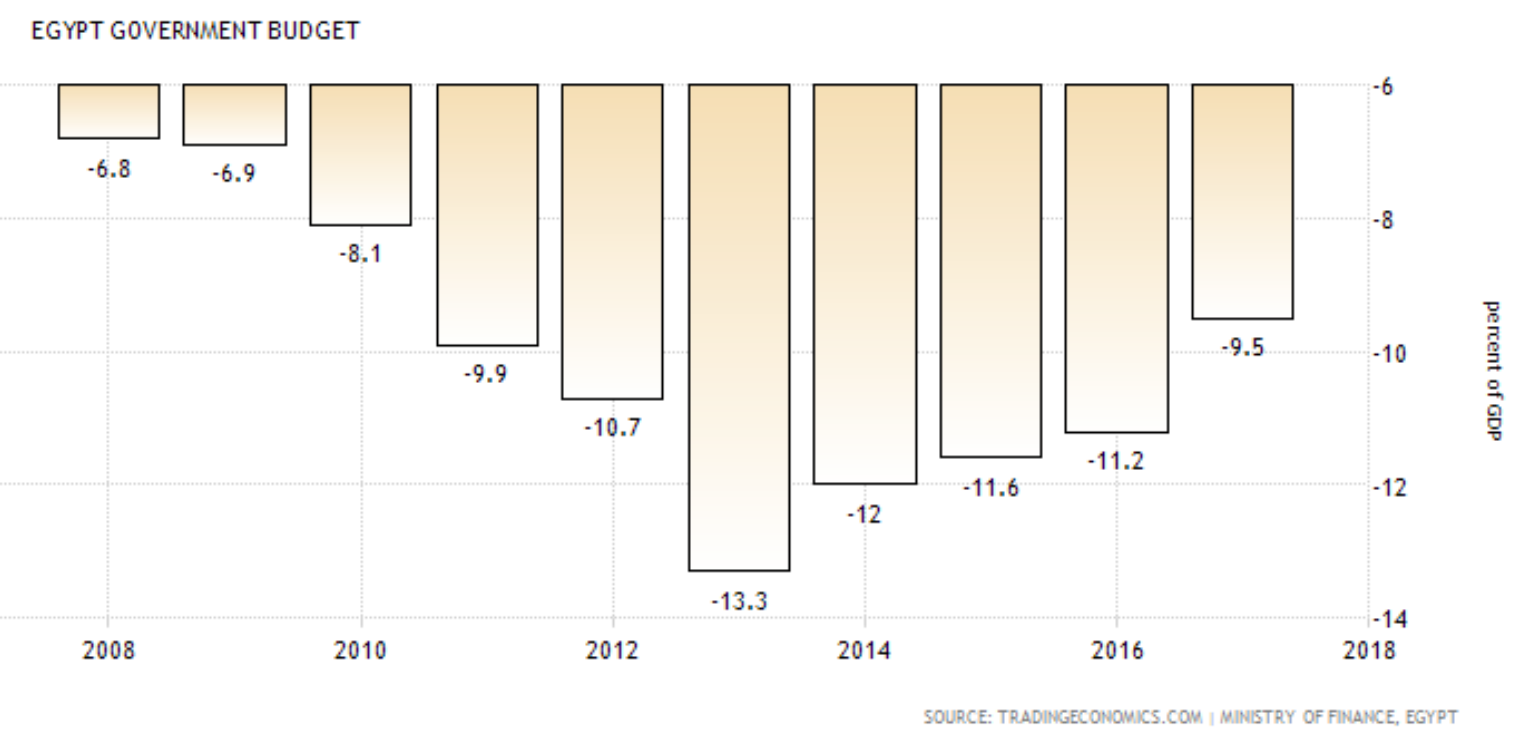

Figure 2. The Egyptian government budget as a \% of GDP from 2008 to 2018

As shown in Figure 2, Egypt had a government budget deficit equal to $9.50 \%$ of the country's Gross Domestic Product in 2017. The average budget deficit from 2002 until 2017 was $-9.72 \%$ of GDP.

EGYPT GDP ANNUAL GROWTH RATE

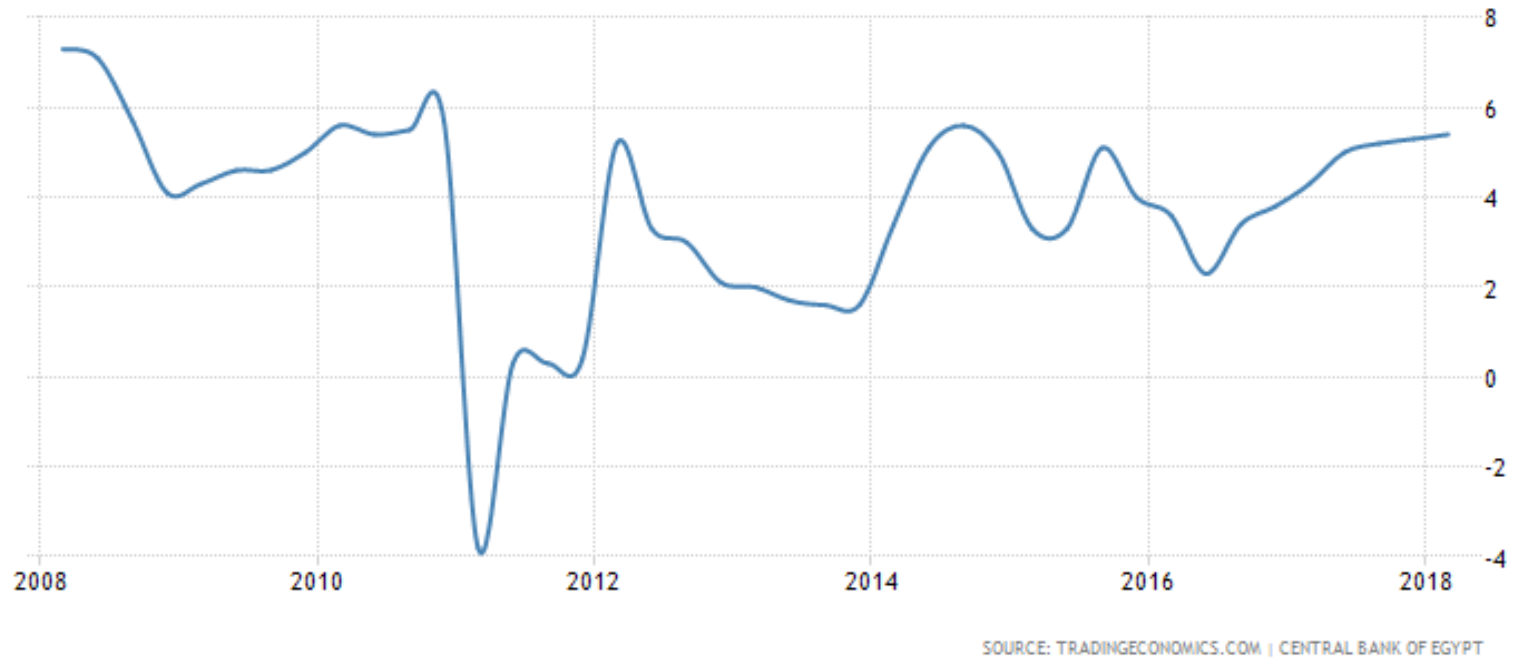

Figure 3. The Egyptian annual growth rate from 2008 to 2018

While in Figure 3, the GDP annual growth rate is depicted, showing an increase in the last two years 2017 and 2018. It became 5.40\% in the first quarter of 2018, up from 5.3 percent in 
the previous period. The average growth rate was $4.07 \%$ from 1992 until 2017, reaching a high of 7.70 percent in the fourth quarter of 2007 and a record low of -3.80 percent in the first quarter of 2011.

\section{Limitations of the Study}

The paper focuses mainly on identifying the relationship between public debt and economic growth in Egypt post- revolutionary stage, through examining the literature and historical trends and some statistical illustrations. The paper does not examine the relationship between public debt on economic growth using a statistical model, integrating other factors as well, that could be of similar importance as the public debt on economic growth. This calls for further investigations in future researches. Also, I found little discrepancy in the numbers of the data collected from different sources, which could bias the results of that relationship in some respect.

\section{Recommendations for Policymakers}

1. The government should allocate in a more efficient way the public expenditures to curtail the steady rise in the percentage of expenditures to GDP.

2. Restructuring the revenue sources is important to generate fiscal surplus, and help maintain and probably even decrease the long term debt/GDP ratio.

3. Reforming the tax system is a key factor in sustaining debt.

4. Creating growth enhancing environment to ensure that the economy remains on higher growth path.

5. Supporting capital market development, especially the secondary market for domestic debt instruments; development of a money market represents the important possibility of placing domestic debt (El-Mahdy and Torayeh, 2009).

6. Public spending cuts (austerity measures) is essential to restore the balance to the economy, but this should not include public investment which is essential to growth over the medium and long term.

7. Other debt relief arrangements have to be considered by the government to give it more fiscal relief.

8. The government has to limit borrowing and find other sources to finance its programs.

\section{References}

Abbas, S. A., Akitoby, M. B., Andritzky, M. J. R., Berger, M. H., Komatsuzaki, M. T., \& Tyson, J. (2013). Dealing with high debt in an era of low growth (No. 13-17). International Monetary Fund. https://doi.org/10.5089/9781484316139.006

Abbas, S. M. (2007). Public Domestic Debt and Growth in LICs. Draft doctoral thesis paper (Oxford, United Kingdom, University of Oxford). Available via the Internet: users. ox. ac. uk/Bhert1734/Publicpercent20domesticpercent20debtpercent20andpercent 20growth. pdf. 


\section{1) Macrothink}

Business and Economic Research ISSN 2162-4860 2018, Vol. 8, No. 3

Abbas, S. M., \& Ali, B. (2004). Public debt sustainability and growth in post-HIPC Sub-Saharan Africa: the role of DD. Paper for GD Net's, 5.

Abutaleb, A. S., \& Hamad, M. G. (2012). Optimal foreign debt for Egypt: A stochastic control approach. Economic Modelling, 29(3), 544-556.

https://doi.org/10.1016/j.econmod.2011.12.006

Afxentiou, P. C., \& Serletis, A. (1996). Foreign Indebtedness in Low-and Middle-Income Developing Countries. Social and Economic Studies, 133-159.

Alba, P., Shawarby, S., \& Iqbal, F. (2004). Fiscal and public debt sustainability in Egypt. World Bank, Middle East and North Africa, the Office of the Chief Economist.

Amadeo, K. (2018, March 29). Public debt and its pros and cons. Retrieved from: https://www.thebalance.com/what-is-the-public-debt-3306294 Accessed on: 07/27/2018.

Amin, G. (2012). The story of the Egyptian economy. $\left(3^{\text {rd }} e d\right)$. El Shorouk.

Blavy, R. (2006). Public debt and productivity: the difficult quest for growth in Jamaica (Vol. 6). International Monetary Fund. https://doi.org/10.5089/9781451864953.001

Cecchetti, S. G., Mohanty, M., \& Zampolli, F. (2011). Achieving growth amid fiscal imbalances: the real effects of debt. In Economic Symposium Conference Proceedings (Vol. 352, pp. 145-96). Federal Reserve Bank of Kansas City.

Chowdhury, A. (2001). External debt and growth in developing countries: a sensitivity and causal analysis. WIDER-Discussion Papers.

Cohen, D. (1993). Low Investment and Large LDC Debt in the 1980's. The American Economic Review, 437-449.

Cunningham, R. T. (1993). The effects of debt burden on economic growth in heavily indebted developing nations. Journal of economic development, 18(1), 115-126.

Deshpande, A. (1997). The debt overhang and the disincentive to invest. Journal of Development Economics, 52(1), 169-187. https://doi.org/10.1016/S0304-3878(96)00435-X

Egypt: Time to entrench growth and make it more inclusive. (2018, January 23). Retrieved from: https://www.imf.org/.../na012318-egypt-time-to-entrench-growth-and-make-it-more-i... Accessed on: 07/19/2018.

El-Mahdy, A. M., \& Torayeh, N. M. (2009). Debt sustainability and economic growth in Egypt. International journal of Applied Econometrics and quantitative studies, 6(1), 21-55.

Elmeskov, J., \& Sutherland, D. (2012). Post-crisis debt overhang: growth implications across countries. Retrieved from: www.oecd.org/dataoecd/7/2/49541000.pdf.

Feldstein, M. S. (1986). Budget deficits, tax rules, and real interest rates.

Flash Note: Reasons and risks of Egypt's public debt. (2015). Retrieved from: https://www.alexbank.com/Cms_Data/Contents/.../Publication/.../egypt_public_debt.pd. 
Accessed on: 07/19/2018.

Fosu, A. K. (1996). The impact of external debt on economic growth in Sub-Saharan Africa. Journal of Economic Development, 21(1), 93-118.

Fosu, A. K. (2007). The external debt-servicing constraint and public expenditure composition: Evidence from African economies (No. 2007/36). Research Paper, UNU-WIDER, United Nations University (UNU).

Habimana, A. (2005). The effects of external debt burden on capital accumulation: a case study of Rwanda (Doctoral dissertation, University of the Western Cape).

Herndon, T., Ash, M., \& Pollin, R. (2014). Does high public debt consistently stifle economic growth? A critique of Reinhart and Rogoff. Cambridge journal of economics, 38(2), 257-279. https://doi.org/10.1093/cje/bet075

Highlights of the Pakistan economic survey 2012-2013. (2013, May 30). Retrieved from: finance.gov.pk/survey/chapters_13/hghlights\%202013.pdf Accessed on: 07/18/2018.

Iqbal, Z., \& Zahid, G. M. (1998). Macroeconomic determinants of economic growth in Pakistan. The Pakistan Development Review, 125-148.

https://doi.org/10.30541/v37i2pp.125-148

Karagol, E. (2012). The causality analysis of external debt service and GNP: The case of Turkey. Central Bank Review, 2(1), 39-64.

Krueger, A. O. (1987). Debt, capital flows, and LDC growth. The American Economic Review, 77(2), 159-164.

Kumar, M. S., \& Woo, J. (2010). Public Debt and Growth, IMF Working Paper, WP/10/174.

Levy, A., \& Chowdhury, K. (1993). An integrative analysis of external debt, capital accumulation and production in Latin America, Asia-Pacific and Sub-Saharan Africa. Journal of Economics and Finance, 17(3), 105-119. https://doi.org/10.1007/BF02920034

Lin, S., \& Sosin, K. (2001). Foreign debt and economic growth. Economics of Transition, 9(3), 635-655. https://doi.org/10.1111/1468-0351.00092

Mahdavi, S. (2004). Shifts in the composition of government spending in response to external debt burden. World Development, 32(7), 1139-1157.

https://doi.org/10.1016/j.worlddev.2004.01.011

Massoud, A. A. (2015). Dealing with the Increasing Public Debt in Egypt. Int'l J. Soc. Sci. Stud., 3, 17.

Megahid, A. (2017). Egypt's growing debts cause for concern. The Arab Weekly, Retrieved from: https://thearabweekly.com/egypts-growing-debts-cause-concern.

Mohamed, H. (2018). Egypt to lower public debt to $80 \%$ by 2020: Finance Min. Egypt today, Retrieved from:

https://www.egypttoday.com/.../3/.../Egypt-to-lower-public-debt-to-80-by-2020-Finan 


\section{Macrothink}

Business and Economic Research ISSN 2162-4860 2018, Vol. 8, No. 3

Nguyen, T. Q., Clements, M. B. J., \& Bhattacharya, M. R. (2003). External debt, public investment, and growth in low-income countries (No. 3-249). International Monetary Fund. https://doi.org/10.5089/9781451875904.001

Ostry, M. J. D., \& Abiad, M. A. (2005). Primary surpluses and sustainable debt levels in emerging market countries (No. 5-6). International Monetary Fund.

Panizza, U., \& Presbitero, A. F. (2014). Public debt and economic growth: is there a causal effect?. Journal of Macroeconomics, 41, 21-41. https://doi.org/10.1016/j.jmacro.2014.03.009

Pattillo, C., Poirson, H., \& Ricci, L. (2002). External debt and growth, IMF Working Paper No. 02/69

Pescatori, A., Sandri, D., \& Simon, J. (2014). Debt and growth: is there a magic threshold? (No. 14-34). International Monetary Fund. https://doi.org/10.5089/9781484306444.001

Public debt in Egypt. (2018). Focus economics. Retrieved from:

http//www.focus-economics.com

Reinhart, C. M., \& Rogoff, K. S. (2010). Growth in a Time of Debt. American Economic Review, 100(2), 573-78. https://doi.org/10.1257/aer.100.2.573

Sachs, J. D. (1990). Developing Country Debt and Economic Performance, Volume 2: Country Studies-Argentina, Bolivia, Brazil, Mexico. NBER Books.

https://doi.org/10.7208/chicago/9780226733203.001.0001

Sachs, J., \& Williamson, J. (1986). Managing the LDC debt crisis. Brookings papers on economic activity, 1986(2), 397-440. https://doi.org/10.2307/2534478

Sawada, Y. (1994). Are the heavily indebted countries solvent?: Tests of intertemporal borrowing constraints. Journal of Development Economics, 45(2), 325-337.

https://doi.org/10.1016/0304-3878(94)90036-1

Sen, S., Kasibhatla, K. M., \& Stewart, D. B. (2007). Debt overhang and economic growththe Asian and the Latin American experiences. Economic Systems, 31(1), 3-11.

https://doi.org/10.1016/j.ecosys.2006.12.002

Serieux, J., \& Samy, Y. (2001, August). The debt service burden and growth: Evidence from low income countries. In WIDER Conference on Debt Relief (pp. 17-18).

Smyth, D. J., \& Hsing, Y. (1995). In search of an optimal debt ratio for economic growth. Contemporary Economic Policy, 13(4), 51-59.

https://doi.org/10.1111/j.1465-7287.1995.tb00731.x

Taghavi, M. (2001). Debt, growth and inflation in large European economies: a vector auto-regression analysis. In Capitalism and Democracy in the 21st Century (pp. 165-179). Physica, Heidelberg. https://doi.org/10.1007/978-3-662-11287-8_9

Warner, A. M. (1992). Did the debt crisis cause the investment crisis?. The quarterly journal of economics, 107(4), 1161-1186. https://doi.org/10.2307/2118384 
Were, M. (2001). The impact of external debt on economic growth in Kenya: An empirical assessment (No. 2001/116). WIDER Discussion Papers//World Institute for Development Economics (UNU-WIDER).

\section{Copyright Disclaimer}

Copyright for this article is retained by the author(s), with first publication rights granted to the journal.

This is an open-access article distributed under the terms and conditions of the Creative Commons Attribution license (http://creativecommons.org/licenses/by/3.0/). 